\title{
ANALYSIS OF INDUSTRIAL STRUCTURE, FIRM CONDUCT AND PERFORMANCE - A CASE STUDY OF THE TEXTILE INDUSTRY
}

\author{
Yueh-Chiang Lee', Yao-Hung Yang ${ }^{2}$ \\ 1 Department of Business Administration, Vanung University \\ 1, Van Nung Rd., Chung-Li, Tao-Yuan 32061, Taiwan, R.O.C \\ ${ }^{2}$ Department of Business Administration, Chung Yuan Christian University \\ No. 200, Chung Pei Rd., Chung Li 32023, Taiwan, R.O.C
}

\begin{abstract}
:
With the analysis of the industrial economic theory structure - conduct - performance model, the study investigates the existence of significant relationship among market structure, conduct and performance. Twelve Taiwan companies are studied during the study period from 2006 to 2012 which are analysed with fixed effect and random effect of panel data and ordinary least squares estimation. The empirical result backs the statement by "Structuralism" that market structure (market share, entry barrier and capital intensity) directly affects firm conduct (R\&D intensity) and performance $(R O A)$.
\end{abstract}

\section{Keywords:}

Structure - conductor - performance, textile industry, structuralism, entry barrier, capital intensity, R\&D intensity

\section{Introduction}

Since 1950, the textile industry in Taiwan by importing raw material in early days, transforming to primary use of raw material provided by local petrochemical industry with imported natural cotton and manmade staple fibres had developed a complete manufacturing circle of upstream, midstream and downstream, which included industries such as manufacturing of manmade staple fibre, spinning, weaving, dyeing, garment and garment accessories. Since development, Taiwan textile has become one of the main sources of supply to the global consumption market of textile. The large-scale investment in the textile industry made Taiwan lower in the production cost of textile than the international market resulting in excess production and the predicament that production meant loss. As the investment environment at home became tough, domestic textile manufacturers in recent years have been actively seeking new stronghold abroad by investing in China and areas such as Southeast Asia and Central America, which leads to structural change in the upstream, midstream and downstream of domestic textile manufacturing. Now upstream and midstream textile manufacturers in Taiwan are the main force while downstream suppliers are located in foreign countries with labour abundance. Textile industry has been the major industry that drives Taiwan economic development and brings foreign exchange income. In particular, fabric is the stimulus to the exportation of Taiwan textile. Fabric manufacturers, in response to change in competitive international market, have created in recent years the vertical integration strategy from fabric to garment, and even to brand development and distribution channel, in order to maintain their competitive advantage. According to the Department of Statistics, Ministry of Economic Affairs, the exports of fabric had increased from USD 4.36 billion in 1990 to USD 7.24 billion in 2012 equivalent to an increase from $42 \%$ to $61 \%$ in export share.
The result of the empirical study made by Su, Yu and Yang(26) demonstrated a nonlinear relationship between agglomeration and productivity of textile manufacturers. That is to say, excessive industrial agglomeration may lead to diseconomies of agglomeration. Moreover, innovation was not common in the textile industry, but R\&D cost had a significantly positive impact on productivity which indicated technology remained great influence on the advancement of productivity in the textile industry (Tsai, Liaw \& Tien(29)). According to the study by Lin (14), Taiwan textile manufacturers had enforced vertical integration, in response to market change, of spinning and weaving industry, or of manufacturers related to weaving, dyeing and garment. Chang(5) with Structure, Conduct, and Performance (SCP) analyzed Taiwan textile industry and found in the study that the asset scale of manufacturer had positive influence on net revenue rather than return on shareholders' equity and return on assets. In terms of the literature above, Taiwan textile industry in response to the change in competitive international market causes considerable transformation in the supply chain of textile industry which motivates further investigation in this paper. In addition, whether manufacturer's R\&D technology is a mediator between market structure and performance is another motive.

\section{Purpose of Research}

Based on the above motives, an SCP framework from the industrial economic theory is adopted in the study to discuss the correlation among market structure, behaviour and performance of Taiwan fabric manufacturers. The purpose is as below. First, market share, entry barrier and capital intensity (market structure) plus R\&D intensity (firm behaviour) are investigated to find out their significant impact on the performance of fabric manufacturers. Next, the mediating effect of R\&D intensity (firm behaviour) on market share, entry barrier and capital intensity plus performance is discussed. 


\section{Literature Review and Research Hypothesis}

As to the determinant for a firm's operational performance, most scholars used SCP model from the industrial economic theory to explain the correlation among market structure, competitive behaviour and operational performance. It was generally concluded that the operational performance of a firm was affected by factors containing market structure and its competitive strategy (Szymanski, Bharadwaj, Varadarajan (25); Santos (22); Gallet (7)). Industrial organization (IO) had considered for a long time that industry environment was the source of firm's profit, that the performance of separate companies was influenced by market structure, and that firm's behaviour was unable to master the industry environment it stayed (Mason (15); Bain (1)). Thus, the scholars above investigating in the assumed condition other firm's behaviours affected by market structure which had a direct impact on performance were grouped as Structuralist. Scherer and Ross (23)and Shepherd (24) following the SCP concept suggested by Mason and Bain developed a more comprehensive structure comprising four dimensions such as basic condition, market structure, firm's behaviour and performance. The school who believed basic condition such as supply and demand in an industry would influence market structure, then firm's behaviours including product R\&D, pricing and advertising strategy, and further operational performance of company was called Behaviourist. Porter (19)suggested market environment was not a pure exogenous factor and affected by firm's behaviour. Nevertheless, Porter's framework derived from the traditional 10 theory in which market structure played a key role in clarification of firm's performance. In Porter's structure, firm's performance was the function for market structure and firm's behaviour (Grant (9); Porter (19)). Market structure may influence the firm's behaviour and the two factors had a mutual influence.

Taiwan textile industry emphasised cotton textile in its initial development. With economic development and in response to import substitution policy, Taiwan textile industry increased the production by importing machinery and raw material to satisfy the domestic demand for cotton textile and opened up the overseas market. Since 1961, manmade staple fibres have been manufactured to fulfil the increasing demand for raw material in the textile industry. In addition to cotton, manmade staple fibres had been used in making textile which rapidly grew in the 60 s as a solid foundation for the future of manmade staple fibres in Taiwan. After the mid-80s, many auxiliary policies and protective tariff were rescinded. Meanwhile, facing the impacts such as wage rise and global increase in protectionism, numerous Taiwan textile manufacturers migrated to China for business opportunity. The export of Taiwan textile has slumped in recent years along with the drop in export unit price. According to the Department of Statistics, Ministry of Economic Affairs, total exports of textile in Taiwan reached USD 11.82 billion in 2012, 7.1\% lower than that in 2011. Regarding the export structure, most were fabrics accounting for $61.3 \%$ of export. Not only is weaving industry the pivot of past and future in terms of manufacturing process, but weave is the main product for export in the textile industry. As to export by our textile industry, China and Hong Kong accounted for
$31.4 \%$ in total; 10 ASEAN nations accounted for $30.9 \%$ in total which was not inferior in scale to the market China and Hong Kong. In 2012, total imports of textile in Taiwan reached USD 3.32 billion, $7.0 \%$ lower than that in 2011. Regarding the import structure, import of garment achieved USD 1.52 billion, which accounted for $45.8 \%, 7.7 \%$ higher than that in 2011 . Textile was mainly imported from China with an import of USD 1.19 billion which accounted for $36.0 \%$ among all imported textile, $3.9 \%$ greater than that in 2011 .

In response to the competition from an international market, China and Southeast Asia have become the key base for garment manufacturing in the world. Our spinning and fabric are exported to the two areas for manufacturing of clothes which are then exported to countries such as the U.S., Europe and Japan. In recent years, fabric manufacturers have created the vertical integration strategy from fabric to garment, and even to brand development and distribution channel, with active investment in R\&D. With an abundant supply of synthetic fibre material, innovative weaving and dyeing technique in Taiwan, the functional textile industry whose industry value chain and cluster advantage are progressively established heads toward the development of differentiated and high value-added products that greatly drive the export of Taiwan textile.

\subsection{Correlation between Market Structure of Textile Industry and Performance}

In the discussion of market structure, structuralists considered market concentration as the most critical variable affecting the profit of a company (Martin (16); Chang \& Lin (4)). Scholars later considered the market share of a company as the source of monopolization because company having greater market share was superior to others in bargaining power (Sherpherd (24); Demsetz (6); Gale \& Branch (8); Ravenscraft (21)). Demsetz (6)believed company with a high market share garnered abnormal profit from such structure. The result of empirical study made by Gale and Branch(8)plus Yen, Yang and Lin (30)supported Demsetz's argument saying an increase in market share augmented the profit of a company through benefit from the economies of scale.

Operational performance indicates the end results produced by the behavioural strategy adopted by a firm in a product market. The study by Tanriverdi and Venkatraman(28)set ROA, ROE and Tobin's $Q$ as the manipulated variables for performance. $\mathrm{ROA}$ is regarded as the performance of textile industry in this study.

Increase in market share of weaving companies makes economies of scale; company with greater market share is superior to other competitors in cost advantage leading to greater profit margin. Therefore, market share is seen as an important market structure for weaving industry. To sum up, the deductive hypothesis is as below.

H1a: The market share postitively influence on performance of firms.

Bain(1)thought entry barrier as a structural factor which blocks 
potential competitors from entering certain industry, and also as a factor for existing companies to obtain economic profit. By building an entry barrier, a company threatens potential competitors and prevents their entrance. Generally speaking, it is not easy for potential entrants to enter an industry when it is with tough entry barrier. Existing companies have better control of cost and raise profit margin for the industry via collaboration or coordination among companies. Mobility barrier is the extension of entry barrier which prevents companies outside the industry from entering certain strategic group; meanwhile it blocks companies from moving to another group from original group to maintain its strategic position (Caves \& Porter (3)). Different strategic groups face different mobility barriers, so some companies can keep long-term advantage; this explains the difference in profitability among companies (Porter (18)). Group shall constantly build mobility barrier to hold steady market share. In brief, mobility barrier indicates all factors that block companies from moving from one strategic position to the other. Due to mobility barrier, companies in some strategic groups are able to hold competitive advantage and keep greater performance, so the mobility barrier is seen as the structural factor that protects the profit making for companies.

According to Chang's (5) study, the asset scale of Taiwan textile manufacturers positively influence net revenue rather than return on shareholders' equity and return on asset. That is to say, a company in larger production scale tends to get order, so the asset scale of a company becomes an entry barrier which blocks new entrants to the industry as well as prevents companies in other groups in the same industry from moving, as a dual protection. Thus, with a higher entry barrier, it is not easy for potential companies to enter an industry; however, existing companies in the industry enjoy abnormal profit (Lin (13); Lin, Shen \& Hung(12)). Therefore, entry barrier is regarded as an important market structure for weaving industry. To sum up, the deductive hypothesis is as below.

$\mathrm{H} 1 \mathrm{~b}$ : The entry barrier positively influence on performance of firm.

Ou, Chen and Lee (17) thought the transformation of input into output made by a company has to consume resources associated with machinery (high ratio of fixed assets) and labour (low ratio of fixed assets); capital intensity means the ratio of machinery to number of employees. According to the study by Huang, Huang and Chang (10), high capital expenditure shows active company investment to increase investment in fixed equipment and decrease cost or quality of product supplied, in order to increase competitiveness on market. Su et al.(26)suggested in their study that a high capital expenditure indicates a company feels optimistic about its future development and is willing to make an investment with confidence in bettering performance. Hence, it is considered in the study that capital intensity can be seen as an important market structure for weaving industry. To sum up, the deductive hypothesis is as below.

H1c: The capital intensity positively influence on perform of firms

\subsection{Correlation between Market Structure of Textile Industry and Firm Behaviour}

To overcome the operational crisis in textile industry in recent years, the government has advocated the concept of "upgrading industry". Many companies in the industry make effort to raise added value of product by, for instance, setting up information sets providing foreign buyers with diversified designs (ODM). Garment manufacturers with own brand (OBM) create a unique brand image to build consumer demand. Also, due to buyer requirement, they have to promptly respond at their production lines, increase merchandise turnover and decrease cost aggregation; in the meantime, they hold a consistent production process from upstream to downstream to lower production cost, advance production efficiency and enhance market competitiveness. According to the study by Su et al. (26), innovation is not common in the textile industry, but R\&D cost has a significantly positive impact on productivity demonstrating technology remains a great influence on the advancement of productivity in the textile industry. R\&D measurement index can be represented through R\&D intensity (Lin et al. (12)). Sun, Huang and Su (27) thought as well that input in R\&D expenditure enhances future competitive advantage of a company and brings more profitable investment opportunities. High input in R\&D expenditure indicates that a company feels optimistic about its future and is willing to make investment. Taiwan's functional textile manufacturers in recent years actively have technical cooperation with companies at home and abroad plus interdisciplinary innovation to enhance competitive advantage, with business diversification produce high value-added products, and offer vertical production (Lin (114)). Thus, R\&D intensity is set as the variable to measure the conduct of weaving companies.

In comparison with other competitors, weaving companies with an increase in market share are likely to, in response to competitive international market, enthusiastically invest in $R \& D$ as well as head toward the development of differentiated and high value-added products. To sum up, the deductive hypothesis is as below.

H2a: The market share positively influence on R\&D intensity.

As there is a high entry barrier, weaving companies in comparison with other competitors hold cost advantage leading to a greater profit margin, and in consequence, they are willing to invest energetically in $R \& D$ for an advancement in production technology. To sum up, the deductive hypothesis is as below.

$H 2 b$ : The entry barrier positively influence on $R \& D$ intensity.

Considerable capital is required in weaving industry. Companies in such industries usually need an enormous amount of capital for costs including factory buildings and production equipment. It is hard for average owners to finance with such a huge amount. Companies with a higher capital intensity show R\&D capability. To sum up, the deductive hypothesis is as below.

H2c: The capital intensity positively influence R\&D intensity. 


\subsection{Mediating Effect of Firm Behaviour in Textile Industry}

Industrial Economics is divided into two schools based on the highlight of factors in SCP model: "Structuralism" (Mason (15); Bain (1)) and "Behaviourism" (Grant(9); Porter(19). Structuralist concerns industry level and believes companies in the same industry whose firm behaviour is affected by the market structure show no difference except scale; the market structure directly influences performance. However, behaviourist considers that firm behaviour in SCP model is not just a virtual mediator stated by structuralist. Firm behaviour affects not only performance but industrial structure (Yen, Yang \& Lin (31); Yen et al. (30)). Behaviourism is taken as reference in the study which considers the conduct of weaving companies as an important mediator. Below is the deductive hypothesis with the research framework shown as Figure1.

H3a: R\&D intensity has a mediating effect on the relation between market share and performance of firms.

$H 3 b$ : R\&D intensity has a mediating effect on the relation between entry barrier and performance of firms.

H3c: R\&D intensity has a mediating effect on the relation between capital intensity and performance of firms.

\section{Methodology}

\subsection{Data Source}

The listed and OTC companies on Taiwan Stock Exchange are selected as the sample studied sourced from the database of Taiwan Economic Journal (TEJ). The study period is 20062012. Weaving companies in Taiwan's textile industry are mainly discussed in this paper excluding upstream companies of manmade staple fibre and spinning, and downstream companies of dyeing, garment and garment accessories. A total of 12 companies are studied such as Shinkong, Hongho, Chia Her, I-Hwa, Everest, De Licacy, Wisher, Chang-Ho, Honmyue, Eclat, Kwang Ming and Li Cheng. Analysis with least squares method is conducted in this paper by the application of the software Stata 11.0 in addition to random effect model and fixed effect model of Panel Data. As the data type is year-based and some OTC companies only have annual/semiannual reports resulting in missing financial statement data, those companies whose data is missing or incomplete are excluded. Hence, the data in the study are "balanced".

\subsection{Description of Variables}

The data are gathered from the database of TEJ, financial statement of each company and the market observation postsystem, and then calculated based on the operational definition in Table 1 to be the variables used in this paper.

\subsection{Statistical Method and Procedure}

When data is with characteristics such as time series and crosssection, heteroscedasticity often exists in dependent variables if Ordinary Least Squares Estimation (OLS) is adopted for analysis. The issue on residual autocorrelation in time series causes no efficiency estimation result after an analysis by OLS (Kalton, Kasprzyk, \& McMillen (11)). To solve an estimation bias, Panel Data model can be used by introducing cross-sectional and time series data into a metric model for more effective estimation. When explanatory variables in the model are of serious multicollinearity, bias may occur in the estimation of regression coefficient. Hence, previous to regression analysis, data must be checked if there is serious multicollinearity.

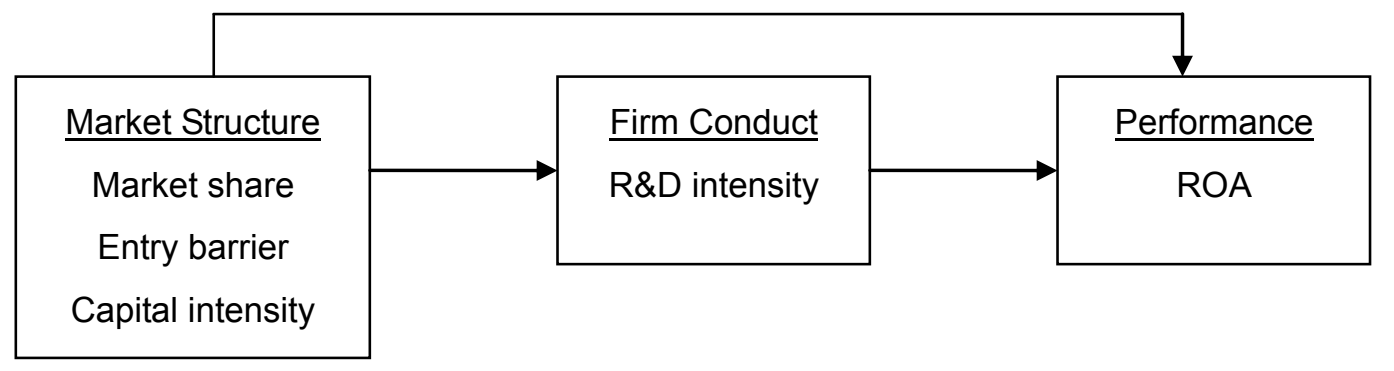

Figure 1. Research framework

Table 1. Definition of Variables

\begin{tabular}{|c|c|c|}
\hline \multicolumn{2}{|r|}{ Strategy } & Operational definition \\
\hline \multirow{3}{*}{$\begin{array}{l}\text { Market } \\
\text { structure }\end{array}$} & Market share (Yen, et al. (30)) & $\begin{array}{l}\text { Net revenue of the } \mathrm{i}^{\text {th }} \text { financial holdings/total net revenue of } \\
\text { financial holdings }\end{array}$ \\
\hline & Entry barrier (Lin (13); Lin et al.(12)) & Fixed asset/net revenue \\
\hline & Capital intensity (Su, et al.(26)) & Fixed asset/total employees \\
\hline $\begin{array}{l}\text { Firm } \\
\text { behaviour }\end{array}$ & R\&D capability (Sun et al.(26)) & R\&D expenditure/net sales \\
\hline Performance & ROA (Tanriverdi \& Venkatraman (28)) & $\begin{array}{c}\{[\text { Net income }+ \text { Interest }(1-\text { Tax rate })] / \text { Average total assets }]\} \\
\times 100 \%\end{array}$ \\
\hline
\end{tabular}


Ordinary Least Squares Estimation (OLS), a fixed effect model and a random effect model are applied in the study to estimate each hypothesis for the selection of a proper model to get the optimal model fitting and correct estimated value. However, which is the optimal model shall be determined through $F$ test and Hausman test.

\section{Empirical Results}

\subsection{Descriptive Statistical Analysis of Variables}

Table 2 has the mean, standard deviation, minimum and maximum of sample studied for better understanding. The number of samples is 84 in total. For ROA, max. is 20.84 and $\min$. is -15.96 ; for market share, max. is $37.76 \%$ and $\min$. is $1.057 \%$; for entry barrier, max. is 6.152 and $\min$. is 0.2178 ; for capital intensity, max. is 24165 and $\min$. is 357 ; for R\&D intensity, max. is 0.288 and $\min$. is 0 .

\subsection{Collinearity Analysis}

Pearson's correlation analysis is adopted in the study to evaluate mutual influence among variables that causes collinearity problem. It can tell from Table 3 that correlation coefficients among variables in the study are lower than 0.75 indicating no serious high correlation among variables (Portney \& Watkins(20)).

\subsection{Analysis of Empirical Results}

It is discovered from Table 4 that market share has a significantly positive influence on performance $(\beta=0.5128, p<0.1)$, so the empirical result support $\mathrm{H} 1 \mathrm{a}$. Entry barrier has a significantly negative impact on performance $(\beta=-0.8463, p<0.1)$, so the empirical result does not support $\mathrm{H} 1 \mathrm{~b}$. It might be because market demand changes fast, companies facing a high-entry barrier are unable to promptly respond to such market change resulting in impact on performance. Capital intensity does not have significantly positive influence on performance $(\beta=$ $0.7551, p>0.1$ ), so the empirical result does not support $\mathrm{H} 1 \mathrm{c}$. It might be because Taiwan weaving industry is not large in production scale in comparison with international market. The industry mainly focuses on export, so customers tend to find out weaving companies on a relatively large scale in China or Southeast Asian nations, so capital intensity does not have a significantly positive influence on performance.

Market share does not show a significantly positive influence on $R \& D$ intensity $(\beta=-0.0371, p>0.1)$, so the empirical result does not support $\mathrm{H} 2 \mathrm{a}$. It might be because Taiwan weaving industry is not large in scale and the benefit from investment in R\&D is not huge, companies are not devoted to R\&D. Entry barrier has a significantly positive influence on $R \& D$ intensity $(\beta=1.3653, p<0.01)$, so the empirical result supports $H 2 b$. Capital intensity has a significantly negative impact on R\&D intensity $(\beta=-1.4587, p<0.01)$, so the empirical result does not support $\mathrm{H} 2 \mathrm{c}$. It might be because textile industry is highly mature and only little benefit may occur when much of the investment is made in machinery and equipment, companies prefer moving a factory to countries with cheaper land and workforce.

According to the mediating effect test from Table 4 and Figure 2 , the mediator R\&D intensity does not show a significant impact on the relation between market share, entry barrier, and capital intensity and ROA (Baron \& Kenny(2)). Therefore, $R \& D$ intensity does not have a mediating effect on market structure (market share, entry barrier and capital intensity) and performance (ROA). The empirical result does not support $\mathrm{H} 3 \mathrm{a}, 3 \mathrm{~b}$ and $3 \mathrm{c}$.

\section{Conclusion and suggestions}

Textile was once Taiwan's largest industry earning foreign exchange. Due to global competition, companies one after another migrate to China and Southeast Asian nations

Table 2. Descriptive Statistical Analysis

\begin{tabular}{|c|c|c|c|c|c|}
\hline Variable & Obs & Mean & Std. Dev. & Min & Max \\
\hline roa & 84 & 2.017619 & 6.13302 & -15.96 & 20.84 \\
\hline share & 84 & 0.083333 & 0.067927 & 0.010572 & 0.327646 \\
\hline entry & 84 & 1.044713 & 1.466393 & 0.217766 & 6.152786 \\
\hline captial & 84 & 3116.85 & 5352.116 & 357.2445 & 24165.42 \\
\hline rd & 84 & 0.025391 & 0.053949 & 0 & 0.287888 \\
\hline
\end{tabular}

Notes: ROA "roa"; Market share "share"; Entry barrier "entry"; Capital intensity "capital"; R\&D intensity "rd".

Table 3. Correlation coefficient

\begin{tabular}{|c|c|c|c|c|}
\hline & roa & share & captial & entry \\
\hline roa & 1 & & & \\
\hline share & 0.1391 & 1 & 1 & \\
\hline captial & -0.0607 & -0.3185 & 0.7468 & 1 \\
\hline entry & -0.0805 & -0.3595 & -0.1134 & -0.0462 \\
\hline rd & -0.0421 & -0.0633 & 1 \\
\hline
\end{tabular}


Table 4. Empirical results

\begin{tabular}{|c|c|c|c|c|c|}
\hline & & Conductor & & Perormance & \\
\hline & & rd & & roa & \\
\hline \multirow{7}{*}{ Structure } & share & -0.0371 & & 0.5128 & $* * *$ \\
\hline & entry & 1.3653 & $* * *$ & -0.8463 & * \\
\hline & capital & -1.4587 & $* * *$ & 0.7551 & \\
\hline & $F$ & 0.05610 & & 0 & \\
\hline & Hausman & & & 0.1031 & \\
\hline & model & OLS & & Random effect & \\
\hline & R-squared & 0.10460 & & 0.2120 & \\
\hline \multirow{8}{*}{$\begin{array}{c}\text { Mediating effect } \\
\text { test }\end{array}$} & share & & & 0.8069 & $* * *$ \\
\hline & entry & & & -1.6257 & $* * *$ \\
\hline & capital & & & 0.4688 & \\
\hline & rd & & & 0.0272 & \\
\hline & $\mathrm{F}$ & & & 0 & \\
\hline & Hausman & & & 0.0393 & \\
\hline & model & & & Fixed effect & \\
\hline & R-squared & & & 0.2489 & \\
\hline
\end{tabular}

Note: ${ }^{*}<0.1 ;{ }^{* *}<0.05 ;{ }^{* * *}<0.01$

Notes: ROA "roa"; Market share "share"; Entry barrier "entry"; Capital intensity "capital"; R\&D intensity "rd".

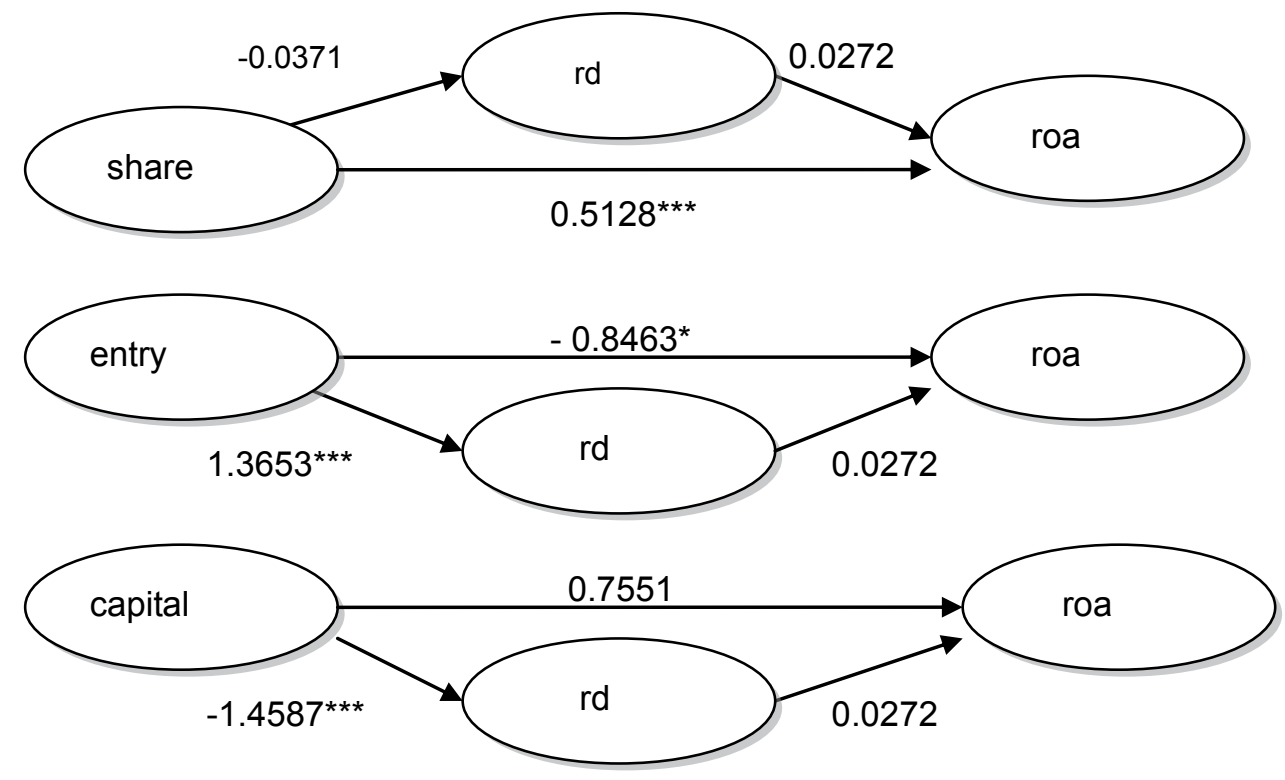

Figure 2. Path Coefficient

to enlarge the effect of scale economies and seek cheap workforce and land. However, Taiwan textile industry in recent years has taken an initiative to vertically integrate supply chain, and meanwhile textile companies actively have technical cooperation with companies at home and abroad plus interdisciplinary innovation to enhance competitive advantage. With a change in the business model of the industry and technical innovation, the importance of company's scale has been lowered. Value activities of the industry, cooperation within the industry and driving force in the industry have been apparently transformed. Thus, Structure - Conduct Performance model as the theoretical framework in the study is applied to analyze 12 Taiwan weaving companies which were listed or OTC during 2006-2012.

According to the result of the study, market share has a significantly positive influence on performance (ROA), which is identical to the results of empirical studies by scholars (Gale \& 
Branch (8); Ravenscraft (21); Lin et al. (12); Yen et al. (30)). This demonstrates that companies with a high market share garner abnormal profit from such structure. Entry barrier has evidently a negative impact on ROA; emergence of inexpensive brand causes rapid change in market demand, so companies facing a high entry barrier are unable to promptly respond to such market change resulting in impact on performance. Entry barrier having obviously positive influence on R\&D intensity assists companies in R\&D innovation and seeking niche while capital intensity has significantly negative impact on R\&D intensity. The above empirical results support the structuralism from the industrial economic theory SCP model (Mason (15); Bain (1)) stating that the market structure directly affects performance and firm behaviour. With regard to the mediator in SCP model - R\&D intensity in the study, the empirical results demonstrate no mediating effect. This indicates that the concept of market structure affecting performance through firm conduct stated by "Behaviourism" (Grant(9); Porter(19); Yen et al(30)) is not verified in the study.

Weaving companies with a high market share earn abnormal profit from such market structure; the emergence of inexpensive brand causes rapid change in market demand, so companies facing a high entry barrier are unable to promptly respond to such market change resulting in an impact on performance. Nevertheless, with a higher entry barrier, companies make much investment in product innovation showing their respect for innovation and R\&D. Sound enterprise system and excellent production technology, in addition to the well understanding of overall market trend and effective resource integration contribute, to the predominance of a company on market. By enhancing international marketing capability, strengthening cooperation with foreign buyers and extending overseas supply chain, Taiwan weaving industry helps the development of our textile industry and export competitiveness. The pursuit of low production cost is not a proper business strategy to Taiwan textile industry. In current market condition, developing a mature and perfect supply technique as an advantage helps Taiwan textile and garment manufacturers survive on market. Taiwan has plenty of fiber raw material supply, innovative weaving and dyeing technology; those advantages of industry chain and cluster have gradually established. In the future, Taiwan textile industries work towards differentiated, a high value-added product development. As mainland China and Southeast Asia for the world's most important clothing making base, so Taiwan should export yarn and fabrics to the two regions, for further processing into clothing and re-export to the United States and Europe and other countries.

\section{Limitation in the Study and Suggestion for Subsequent $\underline{\text { Studies }}$}

1. Data gathering is restricted as some weaving companies in Taiwan are not listed or OTC. If the problem is solved in the future, scholars can discuss the data about all weaving companies to increase the accuracy of industry analysis.

2. In the future, if subsequent researchers are able to get data about foreign companies, a comparison of business SCP model can be made.

\section{References}

[1] Bain, J. S., 1956. "Barriers to New Competition," Cambridge: Harvard University Press.

[2] Baron, R. M. and Kenny, D. A., 1986. "The ModeratorMediator Variable Distinction in Social Psychological Research: Conceptual, Strategic and Statistical Considerations," Journal of Personality and Social Psychology, 51(6), 1173-1182.

[3] Caves, R. E, and Porter, M. E., 1977. "From Entry Barriers to Mobility Barriers: Conjectural Decisions and Contrived Deterrence to New Competition," Quarterly Journal of Economics, 91(2), 241-261

[4] Chan, L. Y. and Lin, H. L., 2012. "The Relationship between Geographic and Market Concentration in Taiwan's Manufacturing Sector," Taipei Economic Inquiry, 49(2), 167-205.

[5] Chang, Y. F., 2012. "Structure, Conduct, and Performance in Taiwan's Functional Textile Industry," Master Dissertation, Soochow University, Taipei.

[6] Demsetz, H., 1973. "Industry Structure, Market Rivalry, and Public Policy," Journal of Law and Economics, 16(1), 1-19.

[7] Gallet, C. A., 1996. "Mergers and Market Power in the US Steel Industry," Applied Economics Letters, 3(4), 221-223.

[8] Gale, B.T. and Brench, B., 1982. "Concentration versus Market Share: What Determines Performance and Why Does it Matter?" Antitrust Bulletin, 27, 83-106.

[9] Grant, R. M., 1991. "The Resource-Based Theory of Competitive Advantage: Implications for Strategy Formulation, California Management Review, 33(3), 114135.

[10] Hung, H. H., Huang, I. H. and Chang, C. H., 2011. "Corporate Performance after Substantial Capital Expenditure: The Role of Growth Opportunity and Corporate Governance," NTU Management Review, 22(1), 297-326.

[11] Kalton, G., Kasprzyk, D. and McMillen, D., 1998. Nonsampling Errors in Panel Surveys. New York: Wiley.

[12] Lin, T.R., Shen, Y. C. and Hung, R. T., 2008. "The An Exploration in the Performance of Taiwan's TFT-LCD Industry: Based on S-C-P Panel Data Model," Taiwan Business Performance Journal," 2(1), 1-29

[13] Lin, C. Y., 2004. "Concentration, Advertising Intensity and Profitability in Taiwan Manufacturing Industries," Taiwan Academy of Management Journal, 4(2), 200-224.

[14] Lin, Y. J., 2005. "The Effectiveness of the Industrial Integration on the Development of a Textiles and Apparel Company," Annual of Tainan Woman's College of Arts \& Technology, 23, 141-162.

[15] Mason, E. S., 1939. "Price and Production Policies of Large Scale Enterprises," American Economic Review, 29(1), 61-74.

[16] Martin, S., 1993. "Advanced Industrial Economics," Oxford UK: Blackwell Publishers.

[17] Ou, C. S., Chen, P. S. and Lee, G. F., 2004. "The Business Value of Training Activities of Taiwan Information and Electronics Industries," Journal of Human Resource Management, 4(4), 51-72.

[18] Porter, M. E., 1980, “Competitive Strategy," New York: Free Press.

[19] Porter, M. E., 1991, "Toward a dynamic theory of strategy." Strategic Management Journal, 12(1), 95-117. 
[20] Portney, L. G. and Watkins, M. P., 2000. Foundations of Clinical Research: Applications to Practice. 2nd edition. Prentice-Hall, Upper Saddle River, NJ.

[21] Ravenscraft, D. J., 1983. "Structure-profit relationships at the line of business and industry level," Review of Economics and Statistics, 65(1), 22-31.

[22] Santos, R. A., 1995. "Dynamics of Market Structure, Advertising and Profitability: A VAR approach," Applied Economics, 27(7), 631-634.

[23] Scherer, F. M. and Ross, D., 1990. "Industrial Structure and Economic Performance," 3thed, New York: Houhgton Mifflin Company.

[24] Shepherd, W. G., 1972. "The Elements of Market Structure," Review of Economics and Statistics, 54(1), 2537.

[25] Szymanski, D. M., Bharadwaj, S. G. and Varadarajan, P. R., 1993. "An Analysis of the Market Share-Profitability Relationship," Journal of Marketing, 57(3), 1-18.

[26] Su, W. C., Yu, Y. T. and Yang, C. H., 2013. "Agglomeration and Productive: Firm Level Evidence from Taiwan's Textile Industry," Taiwan Economic Forecast and Policy, 44(1), 133-160.
[27] Sun, M., Huang, C. J. and Su, C. C., 2013. "M\&As, Divestiture Decisions and Corporate Growth Opportunities," International Journal of Commerce and Strategy, 5(2), 7998.

[28] Tanriverdi, H. and Venkatraman, N., 2005. "Knowledge Relatedness and the Performance of Multi-business Firms," Strategic Management Journal, 26(2), 97-119.

[29] Tsai, S. L., Liaw, G. F. and Tien, Y. N., 2008. "A Study of the Impact of Technology Innovation and Technology Transfer performance by Corporation Technology Development Program In Taiwan Textile Industry," Taiwan Textile Research Journal, 18(3), 72-81.

[30] Yen, G. F., Yang, Y. H. and Lin, W. H., 2013. "Evidence on Structure Conduct Performance - Hypothesis in Taiwan Financial Holding Industry," Economic Survey, 3, 80-85.

[31] Yen, G. F., Yang, Y. H. and Lin, Y. H., 2012. "Research on the Structure and Performance of Financial Holding Industry in Taiwan - The Intermediation Role of Firm Conduct," ICIC Express Letters, 6(10), 2467-2470. 